\title{
BERNADETTA IZYDORCZYK
}

Uniwersytet Jagielloński

Wydział Zarządzania i Komunikacji Społecznej

Instytut Psychologii Stosowanej

30-348, Kraków, ul. Łojasiewicza 4

e-mail: bernadetta.izydorczyk@uj.edu.pl

\section{PSYCHOLOGIA KLINICZNA - SPECJALIZACJA MAJĄCA ZASTOSOWANIE W OCHRONIE ZDROWIA}

\begin{abstract}
Abstrakt. Celem artykułu jest przedstawienie podstawowych danych dotyczących organizacji kształcenia psychologów w zakresie specjalizacji z psychologii klinicznej jako dziedziny, mającej zastosowanie w ochronie zdrowia oraz wskazanie użyteczności kształcenia specjalizacyjnego z psychologii klinicznej i przedstawienie refleksji na temat wad i zalet omawianego programu specjalizacji. Niezależnie od wskazanych braków dotyczących szczególnie samej procedury prowadzenia szkolenia specjalizacyjnego, jego wartością jest to, że daje ono szansę wzbogacania specjalistycznej wiedzy z zakresu psychologii stosowanej i stwarza możliwość jej zastosowania w praktyce wobec człowieka w sytuacji trudnej, związanej z chorobą. Charakteryzując procedurę kształcenia specjalistów psychologii klinicznej, warto podkreślić zasadność przyjętych kierunków tego kształcenia w odniesieniu do współczesnych standardów i celów rozwojowych, związanych z promocją zdrowia psychicznego w krajach Unii Europejskiej. Polityka spójności w zakresie ochrony zdrowia we wszystkich krajach Unii Europejskiej narzuca konieczność wspierania standardów wspomagających całościowe i skoordynowane podejście do ochrony zdrowia psychicznego.
\end{abstract}

Słowa kluczowe: psychologia kliniczna, standardy kształcenia, ochrona zdrowia.

\section{WPROWADZENIE}

Od wielu lat obserwuje się wśród psychologów stale wzrastające zainteresowanie specjalizacją z psychologii klinicznej w dziedzinach mających zastosowanie w ochronie zdrowia. Czynnik ten, w połączeniu ze zwiększającą się stale liczbą psychologów zatrudnionych w służbie zdrowia, wykonujących różnorodne świadczenia zdrowotne na rzecz osób z różnymi zaburzeniami somatycznymi, psychicznymi i trudnościami emocjonalnymi, przyczynił się do podjęcia rozważań prezentowanych w artykule. Praca nie stanowi sprawozdania naukowego z wyników badań własnych czy też doniesienia na podstawie teorii - są to refleksje praktyka-klinicysty na temat aktualnego kształcenia specjalizacyjnego w psychologii klinicznej jako dyscypliny stosowanej w służbie zdrowia. Celem pracy jest przede wszystkim przedstawienie podstawowych kierunków kształcenia 
specjalizacyjnego psychologów w zakresie psychologii klinicznej w kontekście realizowanych w polityce zdrowotnej celów związanych z ochroną zdrowia psychicznego. Szkolenie specjalizacyjne psychologów klinicznych realizowane jest w ramach programu Centrum Medycznego Kształcenia Podyplomowego na mocy rozporządzenia Ministra Zdrowia z dnia 30 września 2002 r. w sprawie uzyskiwania tytułu specjalisty w dziedzinach mających zastosowanie w ochronie zdrowia (Dz. U. nr 173, poz. 1419). Aktualnie oczekujemy na nowelizację tego rozporządzenia ministra zdrowia, która wskazuje i utrzymuje w mocy potrzebę kształcenia podyplomowego specjalistów w dziedzinie psychologii klinicznej. Przedstawione w niniejszym artykule krótkie wprowadzenie w zagadnienia polityki zdrowotnej w Polsce na lata 2016-2020 wskazuje potrzebę uwzględnienia w realizacji celów na rzecz ochrony zdrowia psychicznego także standardów związanych z kształceniem psychologów klinicznych.

Warto podzielić się refleksjami na temat realizacji programu specjalizacyjnego z psychologami-praktykami, albowiem doniesień na ten temat w czasopismach naukowych promujących wiedzę z zakresu psychologii klinicznej jako nauki stosowanej mamy niewiele. W 2009 r. ukazał się artykuł Małgorzaty Basińskiej, w którym autorka z pozycji praktyka-psychologa, a jednocześnie teoretyka-badacza, poza wskazaniem użyteczności wznowienia od 2009 r. kształcenia specjalizacyjnego w dziedzinie psychologii klinicznej, zwraca uwagę na niejednoznaczności dotyczące założeń szczegółowych, zarówno teoretycznego, jak i praktycznego (klinicznego) kształcenia, o którym mowa (Basińska, 2009). Biorąc pod uwagę przedstawione w tym artykule treści dotyczące charakterystyki polityki zdrowotnej w kontekście kształcenia psychologów klinicznych, niezależnie od wskazanych i niewątpliwych braków w programie i procedurze szkolenia specjalizacyjnego, jego niezbywalną wartością jest to, że daje szansę pogłębienia wysoce specjalistycznej wiedzy z zakresu psychologii klinicznej i możliwość jej zastosowania w praktyce wobec człowieka chorego. Departament Nauki i Szkolnictwa Wyższego przy Ministerstwie Zdrowia zajmuje się m.in. nadzorem nad kształceniem podyplomowym kadr medycznych (w tym psychologów klinicznych), prowadzi także sprawy z zakresu powoływania oraz działalności konsultantów krajowych w ochronie zdrowia (m.in. konsultanta krajowego w dziedzinie psychologii klinicznej). Psychologia kliniczna stanowi jedną $\mathrm{z}$ dyscyplin medycznych $\mathrm{i}$ jest na stałe wpisana $\mathrm{w}$ działania mające zastosowanie w ochronie zdrowia. Szkolenie specjalizacyjne w tej dziedzinie daje możliwość podnoszenia kwalifikacji zawodowych na równi z kształceniem specjalizacyjnym lekarzy, zdobywających w jego wyniku dyplom specjalisty określonej dyscypliny medycznej, po przystąpieniu do egzaminu państwowego przed Centralną Komisją Egzaminacyjną Centrum Medycznego Kształcenia Podyplomowego przy Ministerstwie Zdrowia. Podobnie zorganizowana jest procedura zdobywania dyplomu specjalisty psychologii klinicznej,

Zanim zostanie przedstawiony krótki raport dotyczący aktualnego stanu kształcenia specjalizacyjnego psychologów klinicznych w Polsce, warto zwrócić 
uwagę, w jakim stopniu omawiane kształcenie kadr psychologicznych pozostaje w spójności z celami rozwojowymi realizowanej w Polsce polityki zdrowotnej i ochrony zdrowia psychicznego.

\section{PSYCHOLOGIA KLINICZNA A POLITYKA ZDROWOTNA W POLSCE (LATA 2014-2020)}

Charakteryzując strukturę i procedurę kształcenia specjalistów psychologii klinicznej, warto również wskazać zasadność przyjętych kierunków tego kształcenia w odniesieniu do współczesnych standardów i celów rozwojowych dotyczących promocji zdrowia psychicznego w krajach Unii Europejskiej. Polityka spójności $w$ ramach polityki zdrowotnej i ochrony zdrowia psychicznego we wszystkich krajach Unii Europejskiej narzuca konieczność wprowadzania standardów wspierających całościowe i skoordynowane podejście do ochrony zdrowia psychicznego. Standardy te zostały przedstawione w strategii „Europa 2020” i przyjęte przez Komitet Koordynacyjny do spraw Polityki Rozwoju, a także zatwierdzone 8 lipca 2015 r. przez Ministerstwo Zdrowia jako dokument pt. Krajowe ramy strategiczne. Policy paper na rzecz ochrony zdrowia na lata 2014-2020.

Organizacja i program kształcenia specjalizacyjnego w dziedzinie psychologii klinicznej jako dyscyplinie mającej zastosowanie w ochronie zdrowia powinny uwzględniać stojące przed społeczeństwem polskim „zdrowotne wyzwania”. Dotyczą one procesu starzenia się społeczeństwa, przeciwdziałania zaburzeniom psychicznym, chorobom cywilizacyjnym, wykluczeniu społecznemu oraz wzrastającej roli ubóstwa w sytuacji zdrowotnej polskiego społeczeństwa. We wszystkich tych obszarach psychologia kliniczna w ochronie zdrowia winna odnaleźć swoje miejsce, a program kształcenia psychologów klinicznych powinien wspierać politykę zdrowotną.

Z racji celów rozwojowych polityki zdrowotnej w Polsce, tematyka programu teoretycznego i praktycznego kształcenia specjalistów psychologii klinicznej powinna m.in. nawiązywać do kompleksowej problematyki profilaktyki, diagnozy i terapii psychologicznej w zakresie zaburzeń psychicznych u dziecka i człowieka dorosłego oraz zagadnień neuropsychologii i psychosomatyki:

- człowieka w okresie starości;

- problematyki profilaktyki i leczenia zaburzeń psychicznych, m.in. depresji;

- problematyki profilaktyki i pomocy w leczeniu chorób cywilizacyjnych (np. chorób krążenia, cukrzycy, nowotworów);

- profilaktyki wykluczenia społecznego i pomocy osobom wykluczonym społecznie;

- profilaktyki i leczenia zaburzeń psychicznych u dzieci i młodzieży.

Chroniąca prawa i zasady postępowania wobec osób z zaburzeniami psychicznymi, wprowadzona w życie w 1994 r., Ustawa o ochronie zdrowia 
psychicznego oraz przyjęty przez Radę Ministrów w 2010 r. Narodowy Program Ochrony Zdrowia Psychicznego, wyznaczają podstawowe standardy postępowania w procesie profilaktyki i postępowania wobec osób z zaburzeniami psychicznymi oraz różnymi trudnościami emocjonalnymi. Psychologia kliniczna jako dyscyplina stosowana w ochronie zdrowia, również w kształceniu specjalizacyjnym psychologów klinicznych, musi uwzględniać obowiązujące ogólne cele rozwojowe dotyczące promocji zdrowia psychicznego w krajach Unii Europejskiej. Podnoszenie kwalifikacji zawodowych psychologów przyczynia się do wzrostu jakości usług świadczonych na rzecz osób chorych. Mimo wielu niedoskonałości rekomendowanego przez Centrum Medyczne Kształcenia Podyplomowego od 2009 r. programu specjalizacji z psychologii klinicznej, uwzględnia on w swojej treści kształcenia tematykę, o której mowa wyżej, nawiązującą do celów realizowanej polityki zdrowotnej w Polsce.

Jednym z priorytetów strategii „Europa 2020” jest wspieranie włączenia społecznego ludności, co oznacza promowanie gospodarki o wysokim poziomie zatrudnienia, zapewniającej spójność społeczną i terytorialną. Zakłada się m.in., że w 2020 r. liczba ludności zagrożonej społecznie (tj. ubóstwem i wykluczeniem społecznym) zmniejszy się o 20 mln, a wskaźnik zatrudnienia w UE zwiększy się do 75\%. Polska założyła zwiększenie wskaźnika zatrudnienia osób w wieku 20-64 lata co najmniej do 71\% oraz zmniejszenie o 1,5 mln liczby osób zagrożonych ubóstwem i wykluczeniem społecznym. Sprostanie temu wyzwaniu wymaga całościowego, skoordynowanego podejścia do ochrony zdrowia, także psychicznego. Interwencje w dziedzinie ochrony zdrowia są kluczowe w ograniczaniu ryzyka wpadnięcia w ubóstwo z powodu dezaktywizacji zawodowej na tle utraty zdrowia i choroby.

Agencja Oceny Technologii Medycznych i Taryfikacji w 2014 r. rozpoczęła przygotowania do prac nad wyceną świadczeń zdrowotnych, finansowanych ze środków publicznych. Wycenę świadczeń psychiatrycznych uznano za działania priorytetowe, konieczne do podjęcia w 2015 r. W lipcu 2015 r. został także przyjęty przez Komitet Koordynacyjny ds. Polityki Rozwoju, zatwierdzony 8 lipca 2015 r. przez Ministerstwo Zdrowia, wspomniany już w tym artykule dokument pt. Krajowe ramy strategiczne. Policy paper na rzecz ochrony zdrowia na lata 2014-2020. Dokument ten ma wspomóc wdrożenie działań strategicznych, przewidzianych w programach wspólfinansowanych ze środków Unii Europejskiej. Europejskie Biuro Regionalne Światowej Organizacji Zdrowia (WHO) wskazuje potrzebę wspierających działań rządów i społeczeństw na rzecz zdrowia i dobrostanu człowieka XXI w. (2013). Biuro Regionalne Światowej Organizacji Zdrowia na Europę wskazuje konieczność zapewnienia właściwych krajowych ram strategicznych dla realizacji obszarów tematycznych dotyczących ochrony zdrowia (2015).

Zdefiniowane w dokumencie Krajowe ramy strategiczne. Policy paper na rzecz ochrony zdrowia na lata 2014-2020 (2015) podstawowe cele służące ochronie zdrowia to: 
- promocja zdrowia psychicznego i zapobieganie zaburzeniom psychicznym (rozwój profilaktyki zdrowotnej, diagnostyki i medycyny naprawczej ukierunkowane na główne problemy epidemiologiczne w Polsce, zapobieganie zaburzeniom psychicznym: samobójstwom, depresji (opracowanie programów zapobiegania depresji), zwiększenie integracji społecznej osób z zaburzeniami psychicznymi;

- zapewnienie osobom z zaburzeniami psychicznymi wielostronnej i powszechnie dostępnej opieki zdrowotnej oraz innych form opieki i pomocy, niezbędnych do życia w środowisku rodzinnym i społecznym;

- przeciwdziałanie negatywnym trendom demograficznym poprzez rozwój opieki nad matką i dzieckiem oraz osobami starszymi;

- poprawa efektywności i organizacji systemu opieki zdrowotnej w kontekście zmieniającej się sytuacji demograficznej i epidemiologicznej oraz wspieranie badań naukowych, rozwoju technologicznego oraz innowacji w ochronie zdrowia;

- wsparcie systemu kształcenia kadr medycznych w kontekście dostosowania zasobów do zmieniających się potrzeb społecznych;

- rozwój badań naukowych i systemu informacji z zakresu zdrowia psychicznego.

Realizacja wymienionych celów powinna przyczynić się do poprawy opieki zdrowotnej, która w 2020 r. będzie systemem zorientowanym na dłuższe życie $\mathrm{w}$ zdrowiu, potrzeby obecnego i przyszłego pacjenta. Inwestycje w infrastrukturę zdrowotną mają być realizowane w odniesieniu do zdiagnozowanych deficytów oraz mają wspierać poprawę efektywności systemu zdrowotnego.

Analizy epidemiologiczno-demograficzne dla Polski wskazują, że liczba osób w wieku produkcyjnym i przedprodukcyjnym będzie się w najbliższych latach zmniejszać, przy jednoczesnym systematycznym wzroście liczby osób w wieku poprodukcyjnym (Prognoza ludności Polski na lata 2008-2035, GUS, 2008). W dokumencie Krajowe ramy strategiczne. Policy paper na rzecz ochrony zdrowia na lata 2014-2020, analizy epidemiologiczne wskazują, że stan zdrowia ludności polskiej jest gorszy niż ogółu mieszkańców Unii Europejskiej. Dotyczy to zarówno mężczyzn, jak i kobiet. Wyższy poziom umieralności wynika z zagrożenia życia, szczególnie chorobami układu krążenia i chorobami nowotworowymi. Z kolei niezdolność do pracy najczęściej dotyczy takich chorób, jak: choroby układu krążenia (16,2\%), zaburzenia psychiczne i zaburzenia zachowania $(15,9 \%)$, a także choroby układu nerwowego $(9,5 \%)$ i inne.

Informacja o realizacji działań, wynikających z Narodowego Programu Ochrony Zdrowia Psychicznego w 2014 r., przyjętego w drodze rozporządzenia Rady Ministrów z dnia 28 grudnia 2010 r. w sprawie Narodowego Programu Ochrony Zdrowia Psychicznego (Dz. U. 2011, nr 24, poz. 128) wskazuje podobne cele rozwojowe. Program niniejszy, przyjęty dalej na lata 2016-2020, akcentuje potrzebę realizacji takich głównych celów, jak: 
- zapewnienie osobom z zaburzeniami psychicznymi wielostronnej i powszechnie dostępnej opieki zdrowotnej oraz innych form opieki i pomocy, niezbędnych do życia w środowisku rodzinnym i społecznym;

- rozwój badań naukowych i systemów informacyjnych w zakresie zdrowia psychicznego.

Wszystkie przedstawione dokumenty i programy podkreślają potrzebę respektowania celów rozwojowych, które wymagają włączenia $\mathrm{w}$ ich realizację również kadry psychologicznej, wyspecjalizowanej w zakresie psychologii klinicznej człowieka dorosłego, a także dzieci i młodzieży. Tutaj napotykamy problemy kadrowe, wynikające ze stosunkowo małej liczby specjalistów psychologii klinicznej, gwarantujących w pełni profesjonalną realizację wysokospecjalistycznych świadczeń zdrowotnych wobec człowieka chorego.

\section{WSPÓLCZESNA PSYCHOLOGIA KLINICZNA W OCHRONIE ZDROWIA (CELE I ZADANIA)}

Program specjalizacji z psychologii klinicznej, opracowany przez warszawskie Centrum Medyczne Kształcenia Podyplomowego, nawiązuje do raportu grupy roboczej zarządu Amerykańskiego Towarzystwa Psychologicznego (evidence-based practice in psychology - EBPP) (APA, 2006), stąd obejmuje wiedzę o dostępnych wynikach badań, zintegrowaną z praktyką kliniczną, w kontekście indywidualnych cechy klienta, jego preferencji i kultury, z jakiej pochodzi.

Psychologia kliniczna powinna uwzględniać skuteczność swoich diagnostycznych i terapeutycznych działań, popartą badaniami naukowymi oraz wskazywać użyteczność kliniczną stosowanej wiedzy w praktyce psychologicznej wobec pacjenta/klienta i jego rodziny. Wiedza psychologii klinicznej, opartej na dowodach, musi uwzględniać wiedzę taką, która jest naukowa, pochodzi z empirycznego (zawodowego) doświadczenia psychologa oraz jego kompetencji osobowościowych. Praktyka psychologiczna uwzględnia wiedzę, interpersonalne $\mathrm{i}$ intrapsychiczne kompetencje psychologa klinicznego w świadczeniu usług zdrowotnych wobec osoby w sytuacji choroby czy kryzysu, w połączeniu z wynikami badań naukowych, kontekstem kulturowym w przebiegu leczenia oraz wykorzystaniem kompleksowych strategii klinicznych i terapeutycznych.

Polityka spójności w ochronie zdrowia psychicznego zakłada konieczność wspierania standardów całościowego (kompleksowego) skoordynowanego podejścia do realizacji programów kształcenia psychologów klinicznych, świadczących usługi zdrowotne. Zawarte w obowiązującym aktualnie programie specjalizacji podstawowe cele kształcenia i uzyskane kompetencje zawodowe zakładają:

1. Rozwój posiadanej wiedzy z zakresu psychologii klinicznej, nauk medycznych i humanistycznospołecznych, umożliwiającej rozumienie i rozwiązywanie problemów psychologicznych osób chorych. 
2. Nabywanie i doskonalenie umiejętności wykorzystywania wiedzy w działalności diagnostycznej, terapeutyczno-rehabilitacyjnej, eksperckiej, orzeczniczej.

3. Nabywanie i doskonalenie wiedzy i umiejętności, potrzebnych do stosowania psychologicznych metod terapii.

4. Rozwój świadomości metodologicznej.

5. Rozwijanie wysokich standardów funkcjonowania zawodowego (etyka zawodowa) w kontakcie z pacjentem i jego rodziną oraz we współpracy z pracownikami służby zdrowia.

Absolwent studiów specjalizacyjnych, zdając egzamin państwowy przed komisją w dziedzinie psychologii klinicznej, uzyskuje tytuł specjalisty psychologii klinicznej oraz szczególne kwalifikacje umożliwiające:

- samodzielne definiowanie, stawianie klinicznej diagnozy psychologicznej;

- wskazywanie i planowanie postępowania terapeutycznego i/lub rehabilitacyjnego w zakresie wyznaczonym psychologiczną diagnozą pacjenta;

- stosowanie psychologicznych metod leczenia;

- stosowanie psychologicznych metod rehabilitacji;

- wydawanie opinii psychologicznych w sprawach cywilnych, karnych;

- opracowanie programów profilaktyki i promocji zdrowia psychicznego.

Ponadto specjalista psychologii klinicznej będzie uprawniony do:

- udzielania konsultacji;

- wystawiania specjalistycznych opinii i zaświadczeń;

- konsultacji w kwestiach zdrowia publicznego i polityki społecznej;

- edukacji personelu medycznego.

W zależności od wybranej ścieżki kształcenia specjalizacyjnego szczegółowego, absolwent studiów specjalizacyjnych w psychologii klinicznej uzyska także dodatkowe kompetencje szczegółowe, określone programem specjalizacji w dziedzinie psychologii klinicznej, o którym mowa w niniejszym artykule. Streszczając plan teoretycznych i praktycznych obszarów kształcenia w dziedzinie psychologii klinicznej, można w nim wyodrębnić blok podstawowy i blok szczegółowy (tzw. subspecjalizacyjny), pozwalający po odbytym tzw. szkoleniu podstawowym przystąpić do szkolenia odnoszącego się do zdobywania wiedzy klinicznej w zakresie jednej wybranej przez psychologa dyscypliny, tj. zaburzeń psychicznych człowieka dorosłego, neuropsychologii, psychosomatyki lub psychologii klinicznej dzieci i młodzieży. Szczegółowy program kształcenia specjalizacyjnego w dziedzinie psychologii klinicznej można znaleźć na stronie Ministerstwa Zdrowia (http://www.cmkp.edu.pl/ksztalcenie-podyplomowe/ksztalcenie-w-ochronie-zdrowia/progra-my/). Podanie dokładnej liczby placówek akredytowanych, kształcących w Polsce psychologów klinicznych (wraz z aktualną liczbą pozostających w toku kształcenia specjalizacyjnego psychologów) nie jest w pełni możliwe. Niejasność danych dotyczy także wskazania i doprecyzowania liczby psychologów zatrudnionych w placówkach 
służby zdrowia. Przyczyny tego stanu są trudne do jednoznacznego zdefiniowania. Nie znajdziemy także opublikowanych w stosownych rozporządzeniach i innych dokumentach Ministra Zdrowia takich danych, które by w jednoznaczny sposób określały liczbę psychologów zatrudnionych w placówkach medycznych stacjonarnych i ambulatoryjnych (somatycznych czy psychiatrycznych, zarówno dla dzieci, jak i osób dorosłych). Brak jest dokładnych danych statystycznych na temat zatrudnienia psychologów klinicznych w Polsce. Nie posiadamy także jednoznacznie udokumentowanych spisów psychologów z uwzględnieniem ich zatrudnienia $w$ poszczególnych regionach Polski oraz liczby psychologów pracujących w placówkach ambulatoryjnej i stacjonarnej służby zdrowia. Minister zdrowia i NFZ nie dysponują takimi danymi. Sporządzanie zestawienia liczebności oraz specyfiki pracy psychologów-praktyków w służbie zdrowia wydaje się zasadne, aby budować coraz szerszy i precyzyjniejszy opis praktyki psychologicznej w świadczeniach zdrowotnych, udzielanych na rzecz pacjentów w różnym wieku: od okresu dziecięcego po wiek późno dorosły.

Nieco odmiennie przedstawia się sytuacja w zakresie sporządzenia sprawozdań dotyczących liczebności kształcących się psychologów i ośrodków wpisanych na listę ministra zdrowia jako akredytowanych w zakresie kształcenia specjalizacyjnego $\mathrm{w}$ dziedzinie psychologii klinicznej. W tabeli 1 przedstawiono zestawienie liczebności psychologów oraz liczbę ośrodków akredytowanych w ramach kształcenia specjalizacyjnego w dziedzinie psychologii klinicznej, odbywającego się w latach 2015-2019.

Jak wynika z przedstawionych w tabeli 1 danych, rozkład ośrodków akredytowanych, posiadających uprawnienia do kształcenia specjalizacyjnego $\mathrm{w}$ dziedzinie psychologii klinicznej, jest nierównomierny. Obok województw, w których działa kilka ośrodków, są również takie (np. świętokrzyskie), w których dotąd nie uruchomiono żadnego.

Obserwuje się systematyczny wzrost liczby psychologów bez specjalizacji, w trakcie specjalizacji oraz specjalistów psychologii klinicznej, psychoterapeutów oraz terapeutów uzależnień (por. tabela 2). Znacząca część kształcących się terapeutów uzależnień i psychoterapeutów to osoby mające tytuł zawodowy magistra psychologii. W wielu przypadkach kształcący się $\mathrm{w}$ dziedzinie psychoterapii psychologowie jednocześnie zdobywają specjalizację z psychologii klinicznej. Potwierdza to obecną tendencję wzrostu liczby psychologów spełniających wysokie standardy profesjonalnego wykształcenia klinicznego, bo każde z wymienionych szkoleń (specjalizacja z psychologii klinicznej i akredytowane kursy do certyfikatu psychoterapeuty) to szkolenia obejmujące bardzo szerokie spektrum wiedzy teoretycznej i praktycznej, przewidujące w każdym z wymienionych programów 4-letnie szkolenie połączone z regularną superwizją i opieką kierownika specjalizacji przed uzyskaniem rekomendacji osób dopuszczających do egzaminu państwowego. 
Tabela 1. Zestawienie liczebności psychologów oraz liczba ośrodków wpisanych na listę ministra zdrowia jako akredytowanych w ramach kształcenia specjalizacyjnego w dziedzinie psychologii klinicznej w latach 2015-2019

\begin{tabular}{|c|c|c|c|c|}
\hline Województwo & \begin{tabular}{|c|} 
Liczba \\
ośrodków \\
akredytowa- \\
nych \\
\end{tabular} & $\begin{array}{c}\text { Liczba osób } \\
\text { w toku kształcenia } \\
\text { specjalizacyjnego }\end{array}$ & $\begin{array}{l}\text { Czas zakończenia } \\
\text { kształcenia } \\
\text { specjalizacyjnego }\end{array}$ & $\begin{array}{l}\text { Planowany czas } \\
\text { uruchomienia nowe } \\
\text { edycji kształcenia } \\
\text { specjalizacyjnego }\end{array}$ \\
\hline Mazowieckie & 5 & 179 & 2019 & wiosna 2016 \\
\hline Wielkopolskie & 4 & 75 & 2016 & jesień 2016 \\
\hline Małopolskie & 3 & 84 & 2019 & jesień 2015 \\
\hline $\begin{array}{l}\text { Kujawsko- } \\
\text { pomorskie }\end{array}$ & 1 & 24 & 2016-2017 & wiosna 2016 \\
\hline Pomorskie & 2 & 60 & 2016 & jesień 2016 \\
\hline $\begin{array}{l}\text { Zachodnio- } \\
\text { pomorskie }\end{array}$ & 2 & 15 & 2016 & jesień 2015 \\
\hline $\begin{array}{l}\text { Warmińsko- } \\
\text { mazurskie }\end{array}$ & 1 & 12 & 2018 & wiosna 2018 \\
\hline Łódzkie & 2 & 62 & 2016 & 2016 \\
\hline Śląskie & 2 & 61 & 2016 & jesień 2016 \\
\hline Dolnośląskie & 1 & 62 & 2017 & jesień 2017 \\
\hline Opolskie & - & 0 & 0 & 0 \\
\hline Lubelskie & 2 & 55 & 2017 & jesień 2017 \\
\hline Podkarpackie & 1 & 20 & 2019 & 2019 \\
\hline Lubuskie & - & - & - & - \\
\hline Podlaskie & 1 & 30 & 2016 & 0 \\
\hline Świętokrzyskie & - & - & - & - \\
\hline Razem & 25 & 739 & 2016-2019 & $\begin{array}{c}\text { wiosna } \\
2016-2019\end{array}$ \\
\hline
\end{tabular}

Kształcenie w zakresie psychologii klinicznej wspiera rozwój coraz wyższych i efektywniejszych standardów usług psychologicznych w procesie leczenia. Kryteria świadczenia usług psychologicznych w placówkach szeroko pojętej ochrony zdrowia winny uwzględniać omówione zasady praktyki opartej na dowodach (evidence-based practice in psychology - EBPP) (APA, 2006) oraz wspierać tym samym profesjonalne świadczenia usług psychologicznych wobec pacjentów. W tym względzie warto zdefiniować oraz wprowadzić zróżnicowanie tożsamości zawodowej: psychologa, psychoterapeuty i terapeuty zajęciowego. Posiadane wykształcenie, zakres kompetencji zawodowych i sposób realizacji świadczeń zdrowotnych jest w każdym przypadku odmienny. Psychoterapeuta nie musi być psychologiem ani lekarzem (co kilkanaście lat temu było standardem), tym samym nie ma kompetencji przypisanych jedynie psychologowi. Jedynie psycholog jest uprawniony do korzystania $\mathrm{z}$ narzędzi psychologicznych, stawiania diagnozy 
Tabela 2. Charakterystyka liczebności zatrudnienia kadry świadczącej usługi psychologicznej na rzecz osób chorych w ramach świadczeń publicznych NFZ w psychiatrycznej służbie zdrowia i leczenia uzależnień

\begin{tabular}{|c|c|c|c|c|}
\hline $\begin{array}{c}\text { Oddział } \\
\text { Wojewódzki NFZ }\end{array}$ & $\begin{array}{c}\text { Psychologowie } \\
\text { bez specjalizacji }\end{array}$ & $\begin{array}{l}\text { Psychologowie } \\
\text { kliniczni }\end{array}$ & Psychoterapeuci & $\begin{array}{c}\text { Psychoterapeuci } \\
\text { uzależnień }\end{array}$ \\
\hline Mazowieckie & 635 & 226 & 113 & 218 \\
\hline Wielkopolskie & 291 & 99 & 31 & 151 \\
\hline Małopolskie & 364 & 80 & 165 & 80 \\
\hline $\begin{array}{l}\text { Kujawsko- } \\
\text { pomorskie }\end{array}$ & 133 & 63 & 33 & - \\
\hline Pomorskie & 242 & 36 & 33 & 109 \\
\hline $\begin{array}{l}\text { Zachodnio- } \\
\text { pomorskie }\end{array}$ & 97 & 52 & 47 & 65 \\
\hline $\begin{array}{l}\text { Warmińsko- } \\
\text { mazurskie }\end{array}$ & 49 & 20 & 6 & 54 \\
\hline Łódzkie & 160 & 52 & 95 & 103 \\
\hline Śląskie & 524 & 38 & 164 & 233 \\
\hline Dolnośląskie & 243 & 43 & 26 & 84 \\
\hline Opolskie & 75 & 36 & 6 & 34 \\
\hline Lubelskie & 260 & 31 & 24 & 78 \\
\hline Podkarpackie & 183 & 76 & 28 & 73 \\
\hline Lubuskie & 119 & 9 & 8 & 64 \\
\hline Podlaskie & 127 & 11 & 48 & 69 \\
\hline Świętokrzyskie & 102 & 31 & 20 & 65 \\
\hline Razem & 3604 & 903 & 847 & 1480 \\
\hline
\end{tabular}

Źródło: Informacja o realizacji działań... (2015).

psychologicznej, sporządzania opinii i orzeczeń psychologicznych oraz udzielania pomocy i terapii psychologicznej. Warto zwrócić uwagę, że psycholog nie może być zastępowany „osobą prowadzącą psychoterapię” (lub ubiegającą się o certyfikat psychoterapeuty), zwłaszcza wszędzie tam, gdzie konieczna jest diagnostyka psychologiczna rozpoczynająca lub weryfikująca proces leczenia, bez której trudno dobrać sensowne metody terapii, w tym odpowiednie techniki psychoterapii dopasowane do zaburzeń, potrzeb i możliwości pacjenta. Ponadto zauważamy, że termin ,psychoterapia” jest nadużywany, rozumie się pod nim różne oddziaływania psychologiczne, które nie są psychoterapią. Psychoterapia to systematyczny i długotrwały (od kilkunastu tygodni do kilku lat) proces oddziaływania, którego zadaniem jest dokonanie u pacjenta głębszej zmiany sposobu przeżywania, myślenia czy zachowania - ale nie zawsze jest ona konieczna i możliwa do zastosowania w czasie i warunkach, w jakich udzielamy pomocy psychologicznej. Zwykle psychoterapię muszą poprzedzać bardziej doraźne działania, takie 
jak: rozładowanie aktualnego napięcia, wyjaśnianie natury zaburzeń (psychoedukacja), sesje motywacyjne (do podjęcia leczenia i współpracy), interwencja kryzysowa, pomoc $\mathrm{w}$ naprawieniu lub nawiązaniu relacji z bliskimi, elementarny trening codziennej aktywności, samoobsługi, umiejętności społecznych bądź też działania diagnostyczne (np. pogłębiona diagnoza osobowości, systemu rodzinnego, funkcjonowania poznawczego i neuropsychologicznego itd.). Psycholog jest w pełni przygotowany do podjęcia tych oddziaływań. Dlatego zasadne jest, aby w leczeniu pacjentów nie traktować psychologa i psychoterapeuty zamiennie, a częściej korzystać z ich pomocy łącznie bądź wskazywać bardziej adekwatnie, który z nich może spełniać w danej placówce określoną rolę.

Reasumując, psychologia kliniczna w ochronie zdrowia daje możliwości i wspiera zastosowanie naukowej teorii w praktykowaniu psychoterapii, szczególnie przez psychologów pozostających $\mathrm{w}$ toku kształcenia specjalizacyjnego w omawianej dziedzinie.

\section{WNIOSKI}

Psychologia kliniczna jako dyscyplina stosowana w ochronie zdrowia winna ustalać jasne standardy szkolenia, egzaminowania i certyfikowania specjalistów psychologii klinicznej. Zgodnie ze standardami opracowanymi przez APA (2006), praktyka psychologiczna winna być oparta na dowodach. Usługi psychologiczne w ramach świadczeń zdrowotnych powinny uwzględniać specyfikę problemów, zasoby zdrowotne, osobowość, kontekst społeczno-kulturowy oraz preferencje konkretnego pacjenta (APA, 2006). Wszelkie kliniczne decyzje psycholog podejmuje wspólnie z pacjentem, w oparciu o najlepsze i najbardziej adekwatne dowody naukowe, przy uwzględnieniu możliwych kosztów, korzyści oraz dostępnych zasobów i alternatyw. Zaangażowanie aktywnego, świadomego pacjenta jest jednym z kluczowych wymiarów, wpływających na skuteczność usług psychologicznych. Decyzji dotyczących leczenia nigdy nie mogą podejmować osoby niewyszkolone i nieznające specyfiki przypadku konkretnej osoby. Specjalista psychologii klinicznej w XXI w. dysponuje kompetencjami, pozwalającymi powyższe standardy spełnić. Jest on jednocześnie badaczem i praktykiem, który:

- musi poszukiwać związków między teorią i praktyką kliniczną;

- powinien w swoich własnych zawodowych działaniach w praktyce klinicznej wskazywać konieczność scalania wyników badań i teorii;

- powinien integrować wiedzę z wynikami badań i praktyką kliniczną w kontekście cech klienta i kultury (APA, 2006).

W związku z wyzwaniami, jakie stawia przed psychologami klinicznymi współczesna nauka psychologii i praktyka kliniczna w pracy z osobą (pacjentem, klientem) w różnych sytuacjach trudnych, uwzględniając cele rozwojowe spójnej polityki zdrowotnej, program specjalizacji z psychologii klinicznej winien 
podlegać modyfikacji i regularnym zmianom. Zasadne jest wprowadzenie zmian $\mathrm{w}$ programie specjalizacji zgodnie $\mathrm{z}$ aktualnymi standardami praktyki psychologicznej, opartej na naukowych dowodach, oraz z zasadami prowadzonej w Polsce spójnej polityki zdrowotnej. Prace nad zmianami w programie specjalizacji w dziedzinie psychologii klinicznej zostały podjęte w $2016 \mathrm{r}$.

Podsumowując, psychologia kliniczna jako dyscyplina stosowana w ochronie zdrowia, promująca kształcenie specjalistów psychologii klinicznej, winna ustalać jasne standardy szkolenia, egzaminowania i certyfikowania specjalistów. Istotne miejsce $\mathrm{w}$ ustalaniu tych kryteriów powinni zająć przedstawiciele nauki i praktyki klinicznej, wspierani naukową wiedzą na temat standardów praktyki psychologicznej opartej na dowodach i zasadach etyki zawodowej. Działania w zakresie kształcenia powinny pogłębiać związki między teorią i praktyką kliniczną i odwrotnie: między praktyką kliniczną i teorią, co sprzyja zdefiniowaniu i respektowaniu standardów postępowania diagnostycznego i terapeutycznego. Skutkuje to uzyskiwaniem wyższej jakości usług psychologicznych i podnoszeniem statusu zawodowego psychologa.

\section{BIBLIOGRAFIA}

American Psychological Association - APA (2006). Evidence-Based Practice in Psychology. American Psychologist, 61 (4), 271-285.

Basińska M. A. (2009). Specjalizacja z psychologii klinicznej - refleksje praktyka. Polskie Forum Psychologiczne, 14 (2), 176-184.

Informacja o realizacji działań wynikajacych z Narodowego Programu Ochrony Zdrowia Psychicznego w 2014 r. (2015). Warszawa: Ministerstwo Zdrowia.

Jakab Z., Tsouros A. D. (2015). Zdrowie 2020 - Zdrowie i Rozwój Współczesnej Europy. Przegląd Epidemiologiczny, 69, 105-112.

Krajowe ramy strategiczne. Policy paper na rzecz ochrony zdrowia na lata 2014-2020. (2015). Warszawa: Ministerstwo Zdrowia.

Opolski J. T., Wysocki M. J. (2013). „Zdrowie 2020” - Nowe założenia polityki zdrowotnej. Część II. Przeglad Epidemiologiczny, 67, 735-739.

Prognoza ludności Polski na lata 2008-2035 (2008). Warszawa: GUS, http://stat.gov.pl/cps/rde/ xbcr/gus/L_prognoza_ludnosci_PL_2008-2035.pdf [dostęp: 1.09.2016].

Program specjalizacji w psychologii klinicznej (2003). Warszawa: Centrum Medycznego Kształcenia Podyplomowego, http://www.cmkp.edu.pl/ksztalcenie-podyplomowe/ksztalcenie-w-ochronie-zdrowia/pro-gramy/ [dostęp: 1.09.2016].

Ustawa z dnia 19 sierpnia 1994 r. o ochronie zdrowia psychicznego. Dz. U. 2011, nr 231, poz. 1375; 2015, poz. 1916. 


\title{
BERNADETTA IZYDORCZYK
}

\section{CLINICAL PSYCHOLOGY - A SPECIALIZATION AREA APPLICABLE IN HEALTH CARE}

\begin{abstract}
The paper is aimed at presenting some basic data concerning organization of postgraduate education of psychologists in clinical psychology, a specialization area which is applicable in health care It is also planned to emphasize the usefulness of educational programmes aimed at gaining specialization in clinical psychology, and to present their advantages and disadvantages from the perspective of a psychological practitioner. Irrespective of the drawbacks of the specialization training programmes, it is important to point to the fact that they give a chance to expand specialist knowledge in the field of applied psychology and to apply it in practice with individuals who are in difficult health-related situations. While characterizing the procedure of educating clinical psychology specialists, it is also important to consider validity of the directions of postgraduate education with reference to contemporary standards and development objectives concerning the promotion of mental health in the European Union. The cohesion policy concerning health care in all EU countries requires maintaining the standards which support a holistic and coordinated approach to mental health care.
\end{abstract}

Keywords: clinical psychology, education standards, health care. 